Article

\title{
Genomic Profiling for Piroplasms in Feeding Ixodid Ticks in the Eastern Cape, South Africa
}

\author{
Olusesan Adeyemi Adelabu ${ }^{1,2, *}$, Benson Chuks Iweriebor ${ }^{3}$, Anthony Ifeanyi Okoh ${ }^{1,2}$ (i) \\ and Larry Chikwelu Obi ${ }^{3}$ \\ 1 SAMRC Microbial Water Quality Monitoring Centre, University of Fort Hare, Private Bag X1314, \\ Alice 5700, South Africa; AOkoh@ufh.ac.za \\ 2 Applied and Environmental Microbiology Research Group (AEMREG), Department of Biochemistry and \\ Microbiology, University of Fort Hare, Private Bag X1314, Alice 5700, South Africa \\ 3 School of Science and Technology Sefako Makgatho Health Sciences University, Ga-Rankuwa, \\ Pretoria 0204, South Africa; benson.iweriebor@smu.ac.za (B.C.I.); Lawrence.Obi@smu.ac.za (L.C.O.) \\ * Correspondence: aolusesan@ufh.ac.za
}

Received: 20 November 2020; Accepted: 15 December 2020; Published: 18 December 2020

check for updates

\begin{abstract}
Importation of tick-infected animals and the uncontrollable migration of birds and wild animals across borders can lead to geographical expansion and redistribution of ticks and pathogen vectors, thus leading to the emergence and re-emergence of tick-borne diseases in humans and animals. Comparatively, little is known about the occurrence of piroplasms in ixodid ticks in the Eastern Cape, South Africa, thus necessitating this study, which is aimed at detecting piroplasms (Theileria and Babesia) from feeding tick samples collected from cattle, sheep, and goats in selected sites in the Eastern Cape, South Africa. A total of 1200 feeding ixodid ticks collected from farm animals at selected homesteads were first subjected to molecular identification using mitochondrial $12 S$ ribosomal RNA (rRNA) gene by PCR and were further tested for the presence of piroplasms through amplification of the $18 \mathrm{~S}$ rRNA gene via nested-PCR followed by sequencing of the PCR products. The results indicated that 853 (71.1\%) corresponded to the genus Rhipicephalus, 335 (27.9\%) corresponded to genus Amblyomma, and 12 (1\%) corresponded to genus Haemaphysalis. Amblyomma hebraeum and Rhipicephalus appendiculatus were the most common identified ticks from this study. The 18S rRNA nested-PCR revealed that 44 (3.7\%) samples were confirmed positive for Theileria. A homology search for the generated sequences revealed a high percentage identity of 98-98.9\% similarity to T. buffeli, T. orientalis, and T. sergenti in the GenBank. Based on the results obtained herein, we conclude that there is a big diversity of Theileria species; therefore, we suggest that this research should cover more geographical areas in order to reveal the true prevalence of this pathogen in the studied area because this will be a great step in the possible prevention of an outbreak that could have devastating effects on livestock production and human health in both the studied areas and South Africa at large.
\end{abstract}

Keywords: piroplasms; Theileria; Babesia; ixodid; emergence; outbreak

\section{Introduction}

Piroplasms infections caused by pathogenic species of Theileiria and Babesia have been described as vector-borne emerging zoonoses that induce malaria-like syndrome in susceptible humans with previous exposure to infected tick bite [1,2]. Both Theileria and Babesia are haemoprotozoan that have been described as the causative agents for piroplasmoses [3,4]. They have been known to infect various species of domesticated and wild animals, causing major economic losses on livestock production, especially on small hold farmers in endemic geographical regions [5]. 
Parasites are transmitted to various susceptible hosts by different genera of ixodid ticks such as Dermacentor, Amblyomma, Haemaphysalis, Rhipicephalus, Haemaphysalis, and Hyalomma [2,3] during their blood meal. Theileria spp., as sporozoites, swiftly invade mononuclear leukocytes and thereafter develop into macroschizonts, leading to proliferation of the host cell. The genus Theileria has many species of which T. parva and T. annulata have been reported to be the most pathogenic species of major concern to the livestock industry [6,7]. Clinical symptoms of theileriosis include fever followed by depression, nasal discharge, watery secretion from the eyes, enlarged lymph nodes, and anaemia [8] with attendant huge economic losses in endemic areas, especially Asia and Africa [9].

On the other hand, Babesia species are one of the most common tick-transmitted protozoan hemoparasites worldwide and have been described as the second most frequently found parasites, after trypanosomes, in mammalian blood and in a limited number of bird species. Globally, they are seen to have great medical, veterinary, and economic impacts [10,11]. Babesia microti, B. divergens, B. duncani, and B. venatorum are Babesia species that infect humans globally [12].

Several studies have reported the detection of piroplasms in wildlife and livestock in South Africa [13-16], but little information is available about the frequency of ixodid tick species and the prevalence of piroplasm (Theileria and Babesia) pathogens among cattle, sheep, and goats in South Africa. This study therefore reports the occurrence and genomic profiling of piroplasms in Ixodid ticks collected from domestic animals in selected homesteads in the Amatole and O.R Tambo District Municipalities, Eastern Cape, South Africa.

\section{Materials and Methods}

\subsection{Sample Collection}

With the assistance of animal health technicians and animal farm workers, 1200 feeding ticks were collected from farm animals (cattle $=718$, goats $=352$, sheep $=130$ ) into sterile $50 \mathrm{~mL}$ Nalgene tubes containing 70\% ethanol. The samples were collected between July 2017 to April 2018 in selected homesteads in the Amathole and O.R Tambo district municipalities, in the Eastern Cape of South Africa (Figure 1). Efforts were made to adhere strictly to the University of Fort Hare Animal Ethics Committee regulations on animal handling throughout the sampling period. The collected ticks were transported to the Applied and Environmental Microbiology Research Group (AEMREG) laboratory at the Department of Biochemistry and Microbiology at the University of Fort Hare for analyses. Effort was made to ensure that collected ticks from different animals and locations were properly labelled in different tubes for easy identification. Ethical clearance for the study was obtained from the University of Fort Hare research and ethics committee (Reference number: OBI013) and permission to collect samples was sought from farmers and appropriate authorities prior to sample collection.

\subsection{Morphological Identification}

Morphological identification of ticks to species level was carried out upon arrival at the laboratory using morphologic criteria such as scutum formation, capitulum formation, and limb formation [17,18]. Upon identification, the arthropods were stored at $-70{ }^{\circ} \mathrm{C}$ until processed.

\subsection{Genomic DNA Extraction}

Ticks were washed in sterile distilled water 3 to 4 times for total removal of the ethanol in which they had been collected and chopped with a sterile blade in a petri dish containing phosphate buffer saline (PBS). They were then transferred into a $2 \mathrm{~mL}$ centrifuge tube and vortexed. After vortexing, $20 \mu \mathrm{L}$ of Proteinase K (PK) and $200 \mu \mathrm{L}$ of Cell Lysis buffer (CLD) were added to the homogenized samples. The tubes were then incubated at $56^{\circ} \mathrm{C}$ for $2 \mathrm{~h}$ and centrifuged at $15,000 \mathrm{rpm}$ for $1 \mathrm{~min}$, and the supernatants were then aliquoted into a sterile $2 \mathrm{~mL}$ centrifuge tube. Engorged ticks were processed individually while non-engorged ticks of the same species were processed by pooling, taking precautions so that ticks from the same animal were pooled together using the method as described 
by [19]. Following this process, DNA extraction was carried out using the commercially available kit, Promega ReliaPrep ${ }^{\circledR}$ gDNA Tissue Miniprep System (Madison, WI, USA), and the manufacture's protocol was strictly adhered to.

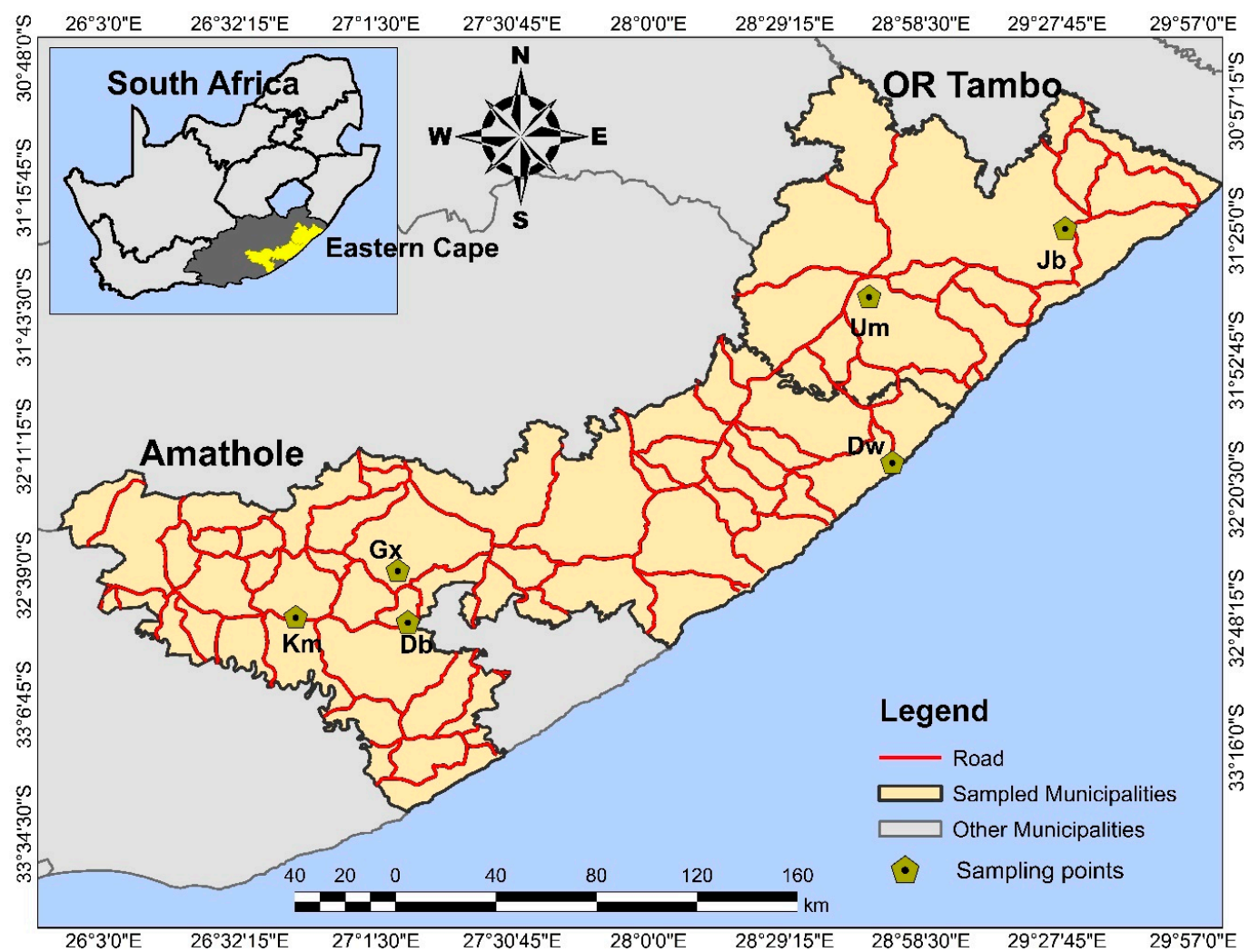

Figure 1. The map showing the geographical locations of the sampling sites with their coordinates; Debe $(\mathrm{Db})=32^{\circ} 52^{\prime} 11.852^{\prime \prime} \mathrm{S}, 2^{\circ} 1^{\prime} 14.171^{\prime \prime} \mathrm{E}$; Gxulu (Gx) = 32 $40^{\prime} 26.702^{\prime \prime}$ S, $27^{\circ} 6^{\prime} 19.591^{\prime \prime}$ E; KwaMemela $(\mathrm{Km})=32^{\circ} 47^{\prime} 38.497^{\prime \prime} \mathrm{S}, 26^{\circ} 44^{\prime} 10.889^{\prime \prime} \mathrm{E}$; Dwesa $(\mathrm{Dw})=32^{\circ} 13^{\prime} 50.916^{\prime \prime} \mathrm{S}, 28^{\circ} 51^{\prime} 16.135^{\prime \prime} \mathrm{E}$; Umtata (Um) $=31^{\circ} 39^{\prime} 26.69^{\prime \prime} \mathrm{S}, 28^{\circ} 48^{\prime} 0.194^{\prime \prime}$ E; Jambini $(\mathrm{Jb})=31^{\circ} 23^{\prime} 36.856^{\prime \prime} \mathrm{S}, 2^{\circ} 29^{\prime} 46.921^{\prime \prime}$ E. Map created using ArcMap 10.5.1.(ArcGIS, Esri, Redlands, CA, USA)

\subsection{Molecular Identification of Tick Species}

For the molecular identification of tick species previously identified morphologically, a fragment of $338 \mathrm{bp}$ of the mitochondrial 12S ribosomal DNA (rDNA) gene was amplified using a set of oligonucleotide 85F 12S [F: 5'-TTAAGCTTTTCAGAGGAATTTGCTC-3'] and 2225 12S [R: 5' TTTAAGCTGCACCTTGAC TTAA-3']. Polymerase chain reaction was performed in a $25 \mu \mathrm{L}$ reaction mixture comprised of master mix; $14 \mu \mathrm{L}$, forward and reverse primers; $1 \mu \mathrm{L}$ each of 10 pmol/L, $4 \mu \mathrm{L}$ of de-ionized water and DNA template; $5 \mu \mathrm{L}$. The conditions used for the amplification were as followes: initial denaturation; $94{ }^{\circ} \mathrm{C}$ for $3 \mathrm{~min}$; $93^{\circ} \mathrm{C}$ for $30 \mathrm{~s}$; denaturation, annealing; $51^{\circ} \mathrm{C}$ for $30 \mathrm{~s}$, elongation at $72{ }^{\circ} \mathrm{C}$ for $60 \mathrm{~s}$, and final elongation at $72{ }^{\circ} \mathrm{C}$ for $5 \mathrm{~min}$.

\subsection{PCR Amplification of Tick-Borne Protozoan Pathogens}

Tick-borne protozoan pathogens were screened for in all extracted genomic DNA for the presence of both Babesia and Theileria species. Two rounds of PCR with two sets of oligonucleotides targeting 18S ribosomal DNA (rDNA) gene for both species, previously reported by [20], was adopted for this study. For the first round of PCR, forward primers (5'-GGCTCATTACAACAGTTATAG-3') and reverse primers (5'-CCCAAAGACTTTGATTTCTCTC- $\left.3^{\prime}\right)$ were used to generate $930 \mathrm{bp}$ while, for the second round of PCR, forward primers (5'-CCGTGCTAATTGTAGGGCTAATAC-3') and reverse primers (5'-GGACTACGACGGTATCTGATCG-3') were used to generate $800 \mathrm{bp}$. Three microliters of extracted 
genomic DNA was added to $22 \mu \mathrm{L}$ reaction mixture comprising $14 \mu \mathrm{L}$ of master mix, $1 \mu \mathrm{L}$ each of $10 \mathrm{pmol} / \mathrm{L}$ of the forward and reverse primers, $4.5 \mu \mathrm{L}$ of RNase nuclease free water, and $1.5 \mu \mathrm{L} \mathrm{MgCl}{ }_{2}$, using the previously reported protocol of [20] with modification in the annealing temperature based on the Tm of the synthesis report of the primers designed by a commercial biotechnology company. For the first round of amplification, the cycling conditions follow were: initial denaturation at $94{ }^{\circ} \mathrm{C}$ for $3 \mathrm{~min}$, denaturation at $93^{\circ} \mathrm{C}$ for $30 \mathrm{~s}$, annealing; $58^{\circ} \mathrm{C}$ for $60 \mathrm{~s}$, elongation; $72{ }^{\circ} \mathrm{C}$ for $1 \mathrm{~min}(40$ cycles), and final elongation; $72^{\circ} \mathrm{C}$ for $7 \mathrm{~min}$. The same cycling conditions were used for the second round of $\mathrm{PCR}$, except for an increase in the annealing temperature to $62{ }^{\circ} \mathrm{C}$ using $3 \mu \mathrm{L}$ of PCR product from the first round of amplification.

The amplification products were analyzed in $1.5 \%$ agarose gel electrophoresis in $0.5 \%$ TBE buffer followed by staining with ethidium bromide. The gel was visualized under UV transilluminator [21]. Bi-directional sequencing was carried out on all the positive amplicons using both forward and reversed oligonucleotides that were used for PCR on the ABI3500xl automated DNA sequencer (Applied Biosystems, Foster, CA, USA) in a commercial sequencing facility.

\subsection{Sequence Editing and Blast Search}

Nucleotide sequences for both forward and reversed strands were assembled and edited to generate consensus sequences for each positive PCR product using the Geneious software program, version 10.1.2 (Biomatters, Auckland, CA, USA) [22].

The sequence data generated after editing were subjected to the BLAST program for homology searching with other curated sequences in GenBank (http://blast.ncbi.nlm.nih.gov). The search parameters were set on highly similar sequences, and sequences with a percentage similarity above $97 \%$ were downloaded for phylogenetic analysis.

\section{Results}

A total of 1200 ticks were randomly removed from domesticated ruminants (cattle, sheep, and goats) from selected homesteads from Amathole and O.R Tambo District Municipalities. Different species of ticks belonging to three genera, Rhipicephalus: 853 (71.1\%), Amblyomma: 335 (27.9\%), and Haemaphysalis: $12(1 \%)$, in decreasing order, were identified in the present study while, at the species level (Figure 2), Amblyomma hebraeum showed the highest occurrence of 335 (27.9\%), followed by Rhipicephalus appendiculatus, 274 (22.8\%); Rhipicephalus decoloratus, 224 (18.7\%); Rhipicephalus evertsi, 200 (16.7\%); and Rhipicephalus microplus, 130 (10.8\%) (Table 1).

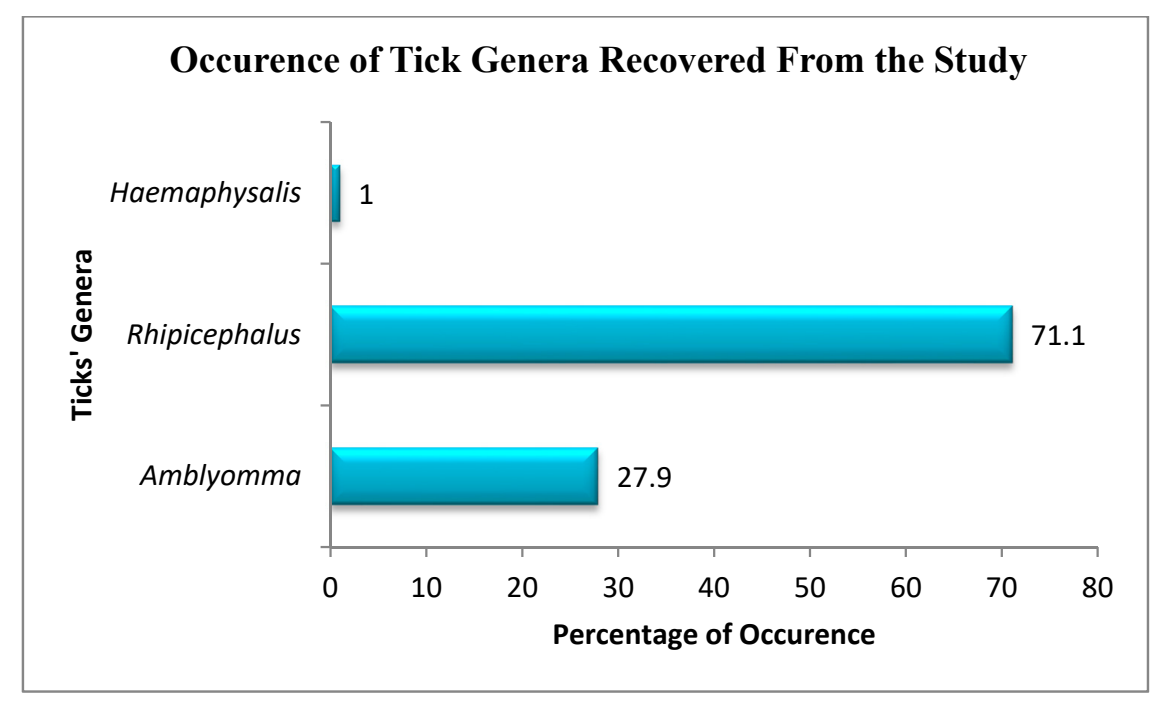

Figure 2. The prevalence of tick genera collected in the study. The figure shows the overall prevalence of tick genera collected at all the sampling sites. 
Table 1. Diversity of Tick Species Collected from the Animals in the Study Areas.

\begin{tabular}{ccccc}
\hline \multirow{2}{*}{ Tick Species } & \multicolumn{3}{c}{ Number of Tick Species per Animal } & \multirow{2}{*}{ Total Number of Ticks (\%) } \\
\cline { 2 - 4 } & Cattle & Goat & Sheep & \\
\hline A. hebraeum & 235 & 80 & 20 & $335(27.9)$ \\
Rh. decoloratus & 129 & 70 & 25 & $224(18.7)$ \\
Rh. sanguineus & 0 & 15 & 5 & $20(1.7)$ \\
Rh. eversti eversti & 140 & 40 & 20 & $200(16.7)$ \\
Rh. microplus & 70 & 40 & 20 & $130(10.8)$ \\
Rh. appendiculatus & 139 & 95 & 40 & $274(22.8)$ \\
Rh. zambeziensis & 5 & 0 & 0 & $5(0.4)$ \\
H. spinulosa & 0 & 12 & 0 & $12(1.0)$ \\
Total & 718 & 352 & 130 & 1200 \\
\hline \multicolumn{4}{c}{}
\end{tabular}

\subsection{Detection of Piroplasms}

Of the 1200 DNA samples assessed for members of the piroplasms, only 44 (3.7\%) samples were confirmed positive for Theileria. A homology search for the generated sequences revealed a high percentage of identity above $95 \%$ with other homologous $18 \mathrm{~S}$ rDNA reference sequences of Theileria spp. in GenBank. Sequences CN1 and CN2 had 96.0\% homology to T. buffeli gene encoding $18 \mathrm{~S}$ ribosomal RNA, T. sergenti-Z15106, T. orientalis-AB520954, T. annulata MF287917, and T. sergenti-AF162431. Subsequently, sequences CN4, CN9,CN23, CN27, CN62, CN64,CN66, CN68, CN79, CN80, and CN174 showed a higher degree of 98\%-98.9\% similarity to T. buffeli (Z15106, AB520953, AY661513, HM538196, HQ840962); Theileria sergenti (GU143088, EU083803, AB668373, EU083803, HM538195); Theileria orientalis (LC325745, AB520954, HM538223, AB668373, MH503862); Theileria orientalis (AB668373, AB520954); and Theileria annulata (MF287934, FJ225392). Other sequences, CN3, CN14, CN18, CN22, CN24, CN30, CN31, CN66, CN69, CN74, and CN76 also demonstrated a high degree of homology between 91.0\%-97.0\% to various Theileria sp. (AP011948, HM538223, EU083803, HM538220, HQ840961, KJ806987, KY197711, XR696404, LC325744, DQ286801, AB000271, KX115426).

However, homologous sequences below $90 \%$ were not reported in this study; hence, four distinct species of Theileria were seen to show a high degree of similarity with the generated sequences in this study.

\subsection{Phylogenetic Analysis of Theileria Pathogen}

The evolutionary history of the generated sequences were further confirmed by subjecting the derived sequence data to phylogenetic analysis with the following reference sequences of the Theileria 18S rRNA gene from GenBank: HM538223-T. sergenti (China), Z15106-T. buffeli (South Africa), JQ437263-T. buffeli (Australia), AB520953-T.orientalis (Australia), MF287917-T. annulata (India), AF162431-Theileria sp. (USA), MF287934- T. annulata (India), JQ037779-Theileria cf. buffeli MC-2012 (India), HQ840964-T. buffeli (Scotland), U97052-Theileria sp. (Japan), AP011946-T. orientalis strain Shintoku (Japan), KJ806987-T. buffeli (China), FJ225391- T. buffeli (Spain), JQ037785-Theileria cf. buffeli MC-2012 (South Africa), JX112733-Theileria sp. RMP-2013 (India), GU143087-T. sergenti (Taiwan), AB000272-T. buffeli (Thailand), HM538209-T. buffeli (China), AY661513-T. buffeli (USA), KX965722-T. buffeli (Korea), AB520958-T. orientalis (Australia), GU143087 (Taiwan), JQ437263-T.sergenti (Australia), DQ287959-T. buffeli (Spain), MH327775-T. buffeli (Algeria), KX965721-T. buffeli (Korea), AB520954-T. orientalis (Australia), HQ840965-T. buffeli (Southern China), FJ426360-T. buffeli (Spain), KX115427-T. sinensis (China), JQ037788-Theileria cf. sinensis MC-2012 (South Africa), LC325745-T. orientalis (Spain), MF287924-T. annulata (India), and JN572700-Theileria sp. B15a (South Africa). The reference sequences were previously aligned the derived sequences using BioEdit sequence alignment editor before the phylogenetic tree was generated using ClustalW in the MEGA7 database [23]. 
The evolutionary history was inferred using the neighbor-joining method [24]. The bootstrap consensus tree inferred from 1000 replicates is taken to represent the evolutionary history of the taxa analyzed [25]. Branches corresponding to partitions reproduced in less than $70 \%$ bootstrap replicates are collapsed. The evolutionary distances were computed using the maximum composite likelihood method [26]. Evolutionary analyses were conducted in MEGA7 [23].

Phylogenetic analysis of generated tick sequences showed that the three genera, Rhipicephalus, Amblyomma, and Haemaphysalis, that were initially identified through morphologic criteria clustered with respective corresponding species of the reference sequences. Sequence T21 clustered in one clade with reference sequences KC503255-Rh. australis, KC503261-Rh. microplus, KC503259-Rh. microplus, and AB075954-Haemaphysalis sp. Additionally, sequences T29, T48, and T29 clustered closely with reference strains AF031859-Rh. appendiculatus, DQ801282-Rh. appendiculatus, KX276945-Rh. appendiculatus, DQ849237-Rh. zambeziensis, DQ849224-Rh. zambeziensis, MF3611814-Rhipicephalis sp., and MF479197-Rh. appendiculatus. Likewise, sequences T01, T4, T13, T20, T25, and T32 clustered together in a clade with reference sequences KF583637-H. longicornis, AF31853-H. longicornis, HQ434625-H. longicornis, AF150049-A. hebraeum, MG076932-A. maculatum, AY342288-A. triste, AY342261-Amblyomma sp., KT386309-Amblyomma sp., and AF150049-A. hebraeum. In addition, obtained sequence T40 revealed high closeness to reference sequences MF479198-Rh. Evertsi, AF150052-Rh. Evertsi, and MF348105-Rh. evertsi, while sequence T10 was found to be closely related to KY676830-Rh. australis, EU9217770-Rh. microplus, AF150045-B. annulatus, and AF031847-B. microplus (Figure 3).

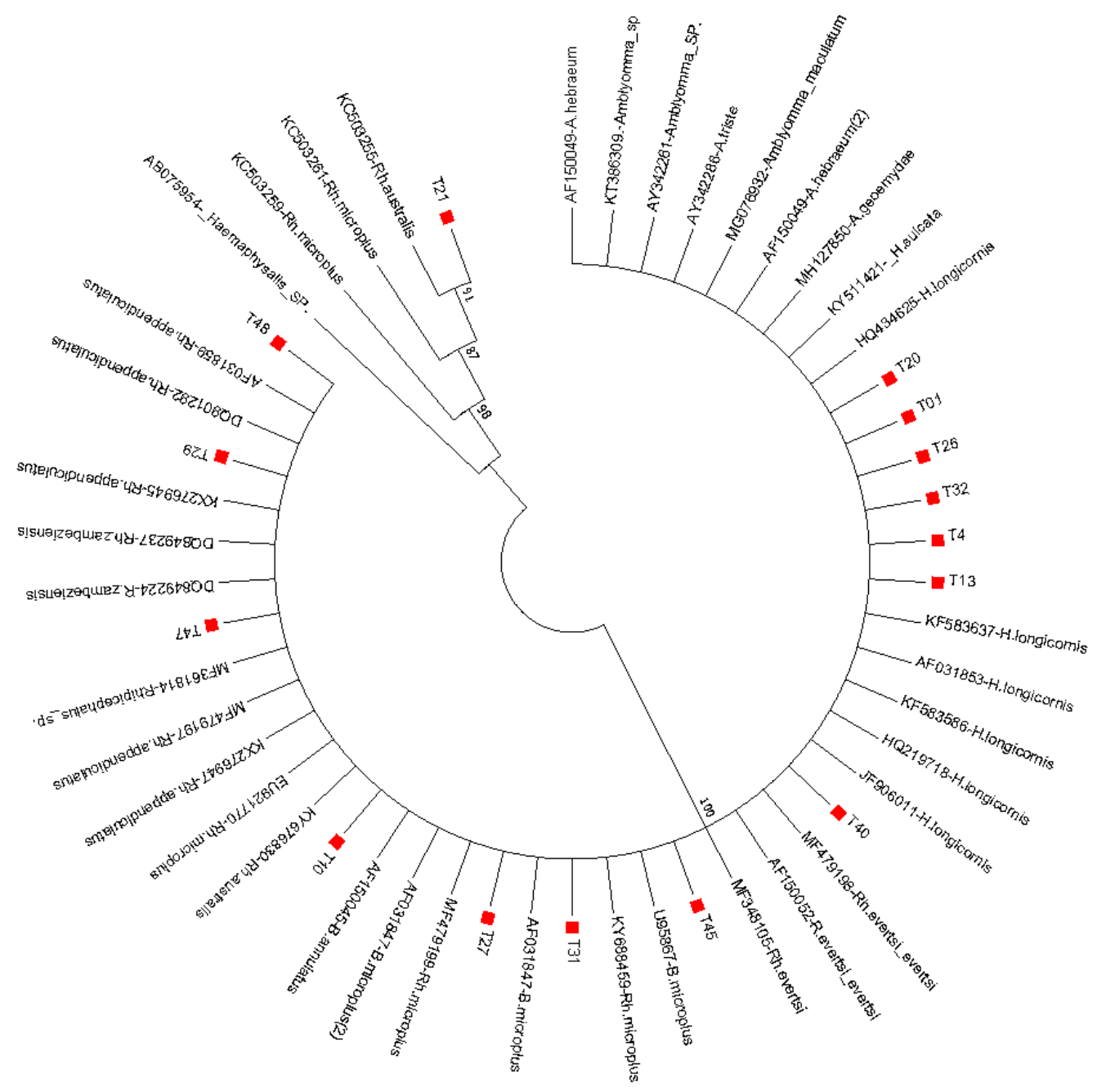

Figure 3. Evolutionary relationships of tick species based on nucleotide sequences of mitochondrial $12 S$ ribosomal RNA gene. 
The evolutionary history was inferred using the neighbor-joining method [24]. The optimal tree, with the sum of branch length $=0.96781808$, is shown. The evolutionary distances were computed using the p-distance method [27] and were in the units of the number of base differences per site. Evolutionary analyses were conducted in MEGA7 [23].

Phylogenetic analysis revealed that all the Theileria sequences obtained in this study clustered into four clades as the majority of the generated sequences clustered unambiguously with each other. Thirteen sequences clustered in a clade with reference sequences HM538209-T. buffeli and MF287924-T. annulata, while two other sequences (CN62 and CN84) were found to cluster between reference sequences MF287924-T. annulata and U97052-Theileria sp. Interestingly, sequences CN1, CN85, and CN21 were found to cluster phylogenetically with reference strains FJ225391-T. buffeli and MF287934-T. annulata, while CN72 and CN125 clustered between LC325745-T. orientalis and HQ840964-T. buffeli (Figure 4).

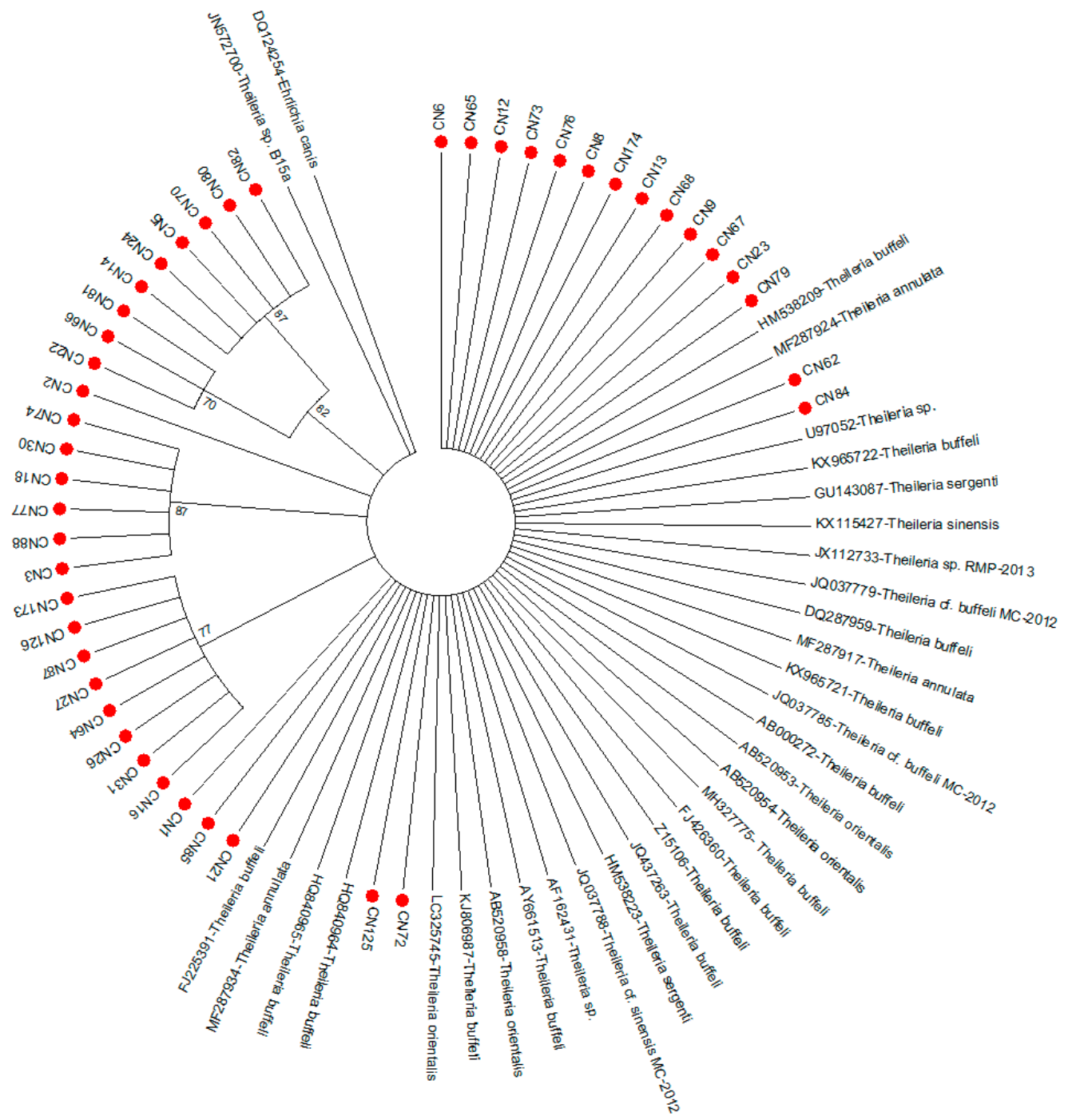

Figure 4. Evolutionary relationships of different Theileria spp. using nucleotides sequence of the $18 \mathrm{~S}$ ribosomal RNA (rRNA) gene.

\subsection{Accession Number}

The nucleotides sequences generated from this study were submitted to GenBank under the following accession numbers: MK347068-MK347111 for Theileria, while the representative sequences were deposited for Amblyomma hebraeum, Rhipicephalus microplus, and Haemaphysalis longicornis under accession number MK347205-MK347212. 


\section{Discussion}

Theileria and Babesia are the two major genera of the Piroplasmorida group belonging to the phylum Apicomplexa. They are tick-borne intracellular haemoprotozoan parasites and have been described to be of global economic, veterinary, and medical significance $[11,28]$. Although human infection due to the theileria pathogen has not been reported, several studies have described human infections caused by Babesia species [29-31]. In this study, only $44(4 \%)$ of the DNA samples were confirmed positive for Theileria pathogens, while none were positive for Babesia. Five distinct species of Theileria (T. sergenti, T. buffeli, T. orientalis, T. annulata, and T. sinensis) were seen to show a high degree of homology to the reference sequences obtained from GenBank.

Different literature has described the T. sergenti, T. buffeli, and T. orientalis groups to be benign bovine protozoan species responsible for major economic losses in the livestock industry and, owing to the high similarity in their serological and morphological cross-reactivity, they are now referred to as T. orientalis $[32,33]$. The pathogenicity and infectivity of each Theileria species have been seen to usually differ from one geographical region to another. For instance, T. buffeli has been seen to be of minor impact in cattle compared to T. parva [34].

Different species of Rhipicephalus, Amblyomma, and Haemaphysalis have been reported as being vectors of Theileria pathogens among domestic and wild animals [35,36]. A prevalence of Theileria pathogens among domestic animals has been reported from different geographical regions of the world such as France [37], Thailand [38], China [39], and Australia [40], as well as in Japan, Italy, Greece, Iran, Ethiopia, and India [41-43].

In Australia, it has been reported that, among the Theileria spp., T. orientalis has been a major concern for several years, especially among cattle, owing to the spread and emergence of the pathogen from wild animals; it has cost the Australian government over $\$ 19$ million yearly, yet no vaccines or chemotherapeutic treatments are available [44]. Likewise, the occurrence of theileriosis caused by T. annulata has been described as being extensive in subtropical regions in the Northern Hemisphere, extending from northern and southern Africa, Europe via the Middle East, and Asia, and it causes an acute theiloriosis similar to tropical theileriosis by T. parva. European breeds of cattle are more susceptible to the infection and suffer a high degree of mortality [33].

Similarly, T. orientalis was reported to be the cause of an outbreak in Australia and New Zealand, with occurrences in a large number of herds and severely affected dairy farms with clinical signs such as haemolytic anaemia, fever, frequent death among the animals, increases in abortion and stillbirths, and drastic reduction in milk productions being observed in most cases [45-49].

Additionally, T. orientalis has been implicated in the outbreak of bovine theileriosis in Burundi; morphological and serological analyses were used to establish its identity, and Amblyomma variegatum was reported as the local tick vector [50]. This study has revealed, for the first time, the occurrence and presence of T. orientalis in southern Africa, as previous studies only described the presence of T. parva from both domestic and wild animals [13,51,52].

Through conventional PCR, a high prevalence of $T$. orientalis has been reported in cattle from different Asia-Pacific regions including Mongolia, 41.7\% [38]; Sri Lanka, 53.5\% [5]; Thailand, 31.5\% [53]; Vietnam, 13.8\% [32]; Myanmar, 36.2\% [54]; and Japan, 64.8\% [55], compared to the $4 \%$ prevalence rate shown in this study, which is however higher than the $0.68 \%$ recently reported in cattle from Egypt [56]. Different factors could be responsible for the variation in the prevalence of $T$. orientalis in different geographical regions, which include the existence and abundance of ticks, susceptibility of animal breeds, wildlife reservoirs, and other environmental or climatic factors.

A free grazing method was observed among the farm animals in the study areas, and this could serve as a perfect platform for the transmission of T. orientalis pathogens from infected tick vectors from the wild. The abundance of African buffalo, being the reservoir host of tick vectors, has been reported in southern Africa, especially the free-ranging African buffalo that usually graze on the same vegetation as farm animals, especially in the study areas [52]. 
Another causative agent of tropical theileriosis detected in this study was T. annulata, second to T.parva among Theileria spp. of high pathogenicity and major economic importance in livestock productions, usually transmitted by Hyalomma ticks. Tropical theileriosis caused by T. annulata is mostly present in southern Europe and northern Africa, spreading through the Middle East, India, and southern Russia into China [57]. High mortality and morbidity rates have been reported in both exotic and indigenous breeds, thus leading to devastating economic losses in livestock production, especially in developing countries $[58,59]$.

The prevalence of theileriosis caused by annulata pathogens has previously been reported in different countries; a prevalence rate of approximately 30\% has recently been reported in Portugal [60], about 76.87\% has been reported in Pakistan [61], 23\% in India [62], 64\% in Egypt [63], 18\% in China [64], and $24 \%$ in Spain [65]. There is a dearth of information on the occurrence of T. annulata in South Africa, except for the report of [66], who reported its occurrence in the country.

Phylogenetic analysis from this study showed that $T$. annulata clustered unambiguously with other reference strains from India, Korea, and Spain; hence, it could be hypothesized that the presence of T. annulata in the studied areas is as a result of migratory wild animals and birds carrying infected ticks with them. Hyalomma ticks have been described as the main vectors of T. annulata worldwide; however, species of Haemaphysalis, which are also endemic in the studied areas, are recently being implicated in its transmission in the Philippines [67].

The universal 18S rRNA gene is commonly reported and used for deducing the phylogeny of different eukaryotic organisms as well as for delineating the species and strains/genotypes of Theileria and Babesia species $[16,66,68]$. It has been used to identify various distinct genotypes of Theileria in various reservoir hosts worldwide, including ruminants and wild animals $[53,56,69,70]$. Phylogenetic analysis of the derived sequences based on the 18S rRNA gene in this study showed that all the Theileria sequences clustered into four clades, which suggests that the obtained sequences could be polymorphic in nature. Theileria sequences form this study showed a high genetic similarity to those from Spain, Korea, Thailand, and Japan, which is supported by the findings of [64].

\section{Conclusions}

This study has revealed the presence of $T$. annulata from ticks collected from domesticated animals for the first time in the studied areas. Based on the results obtained herein, we conclude that there is a big diversity of Theileria species, therefore we suggest that further research should be conducted that will cover more geographical areas. It would also be good to test the animals for the presence of theilerial pathogens in order to establish the true prevalence and population dynamics of ticks throughout the year and to determine the seasonality of this pathogen in the studied area. This would be a great step in the possible prevention of an outbreak that could have a devastating effect on livestock production in both the studied areas and South Africa at large.

Author Contributions: Conceptualization, O.A.A. and B.C.I.; methodology, O.A.A.; software, O.A.A.; validation, B.C.I.; formal analysis, O.A.A.; investigation, O.A.A.; resources, A.I.O.; data curation, O.A.A.; writing-original draft preparation, O.A.A.; writing-review and editing, B.C.I., L.C.O. and A.I.O.; visualization, O.A.A.; supervision, B.C.I., A.I.O. and L.C.O.; project administration, A.I.O. and B.C.I.; funding acquisition, B.C.I., A.I.O. and L.C.O. All authors have read and agreed to the published version of the manuscript.

Funding: This research was funded by [South African Medical Research Council] grant number [OBI013].

Acknowledgments: The authors thank the University of Fort Hare's Research Ethics Committee (UREC) for approval of this study and a special appreciation to the South African Medical Research Council (SAMRC) for the grant released to carry out this study. Our appreciation also goes to the farmers in the study area for their assistance during the collection of samples.

Conflicts of Interest: All authors declare no conflict of interest. 


\section{References}

1. Gabrielli, S.; Calderini, P.; Cassini, R.; Galuppi, R.; Tampieri, M.P.; Pietrobelli, M.; Cancrini, G. Human exposure to piroplasms in Central and Northern Italy. Vet. Ital. 2014, 50, 41-47.

2. Hassan, M.A.; Liu, J.; Rashid, M.; Iqbal, N.; Guan, G.; Yin, H.; Luo, J. Molecular survey of piroplasm species from selected areas of China and Pakistan. Parasites Vectors 2018, 11, 457. [CrossRef]

3. Gebrekidan, H.; Gasser, R.B.; Baneth, G.; Yasur-Landau, D.; Nachum-Biala, Y.; Hailu, A.; Jabbar, A. Molecular characterization of Theileria orientalis from cattle in Ethiopia. Ticks Tick-Borne Dis. 2016, 7, 742-747. [CrossRef]

4. Peckle, M.; Pires, M.S.; da Silva, C.B.; da Costa, R.L.; Vitari, G.L.V.; Senra, M.V.X.; Dias, R.J.P.; Santos, H.A.; Massard, C.L. Molecular characterization of Theileria equi in horses from the state of Rio de Janeiro, Brazil. Ticks Tick-Borne Dis. 2018, 9, 349-353. [CrossRef]

5. Sivakumar, T.; Hayashida, K.; Sugimoto, C.; Yokoyama, N. Evolution and genetic diversity of Theileria. Infect. Genet. Evol. 2014, 27, 250-263. [CrossRef]

6. Nene, V.; Morrison, W.I. Approaches to vaccination against Theileria parva and Theileria annulata. Parasite Immunol. 2016, 38, 724-734. [CrossRef]

7. Zweygarth, E.; Nijhof, A.M.; Knorr, S.; Ahmed, J.S.; Al-Hosary, A.T.; Obara, I.; Bishop, R.P.; Josemans, A.I.; Clausen, P.H. Serum-free in vitro cultivation of Theileria annulata and Theileria parva schizont-infected lymphocytes. Transbound. Emerg. Dis. 2020, 67, 35-39. [CrossRef]

8. Abdallah, M.O.; Niu, Q.; Yang, J.; Hassan, M.A.; Yu, P.; Guan, G.; Chen, Z.; Liu, G.; Luo, J.; Yin, H. Identification of 12 piroplasms infecting ten tick species in China using reverse line blot hybridization. J. Parasitol. 2017, 103, 221-227. [CrossRef]

9. Jabbar, A.; Abbas, T.; Saddiqi, H.A.; Qamar, M.F.; Gasser, R.B. Tick-borne diseases of bovines in Pakistan: Major scope for future research and improved control. Parasites Vectors 2015, 8, 283. [CrossRef]

10. Schnittger, L.; Rodriguez, A.E.; Florin-Christensen, M.; Morrison, D.A. Babesia: A world emerging. Infect. Genet. Evol. 2012, 12, 1788-1809. [CrossRef]

11. Chisu, V.; Alberti, A.; Zobba, R.; Foxi, C.; Masala, G. Molecular characterization and phylogenetic analysis of Babesia and Theileria spp. in ticks from domestic and wild hosts in Sardinia. Acta Trop. 2019, 196, 60-65. [CrossRef]

12. Ord, R.L.; Lobo, C.A. Human babesiosis: Pathogens, prevalence, diagnosis, and treatment. Curr. Clin. Microbiol. Rep. 2015, 2, 173-181. [CrossRef]

13. Chaisi, M.E.; Sibeko, K.P.; Collins, N.E.; Potgieter, F.T.; Oosthuizen, M.C. Identification of Theileria parva and Theileria sp. (buffalo) 18S rRNA gene sequence variants in the African Buffalo (Syncerus caffer) in southern Africa. Vet. Parasitol. 2011, 182, 150-162. [CrossRef]

14. Berggoetz, M.; Schmid, M.; Ston, D.; Wyss, V.; Chevillon, C.; Pretorius, A.M.; Gern, L. Tick-borne pathogens in the blood of wild and domestic ungulates in South Africa: Interplay of game and livestock. Ticks Tick-Borne Dis. 2014, 5, 166-175. [CrossRef]

15. Ringo, A.E.; Moumouni, P.F.A.; Taioe, M.; Jirapattharasate, C.; Liu, M.; Wang, G.; Gao, Y.; Guo, H.; Lee, S.H.; Zheng, W.; et al. Molecular analysis of tick-borne protozoan and rickettsial pathogens in small ruminants from two South African provinces. Parasitol. Int. 2018, 67, 144-149. [CrossRef]

16. Bhoora, R.V.; Collins, N.E.; Schnittger, L.; Troskie, C.; Marumo, R.; Labuschagne, K.; Smith, R.M.; Dalton, D.L.; Mbizeni, S. Molecular genotyping and epidemiology of equine piroplasmids in South Africa. Ticks Tick-Borne Dis. 2019, 11, 101358. [CrossRef]

17. Horak, I.G. Parasites of domestic and wild animals in South Africa. XXXVII. Ixodid ticks on cattle on Kikuyu grass pastures and in Valley Bushveld in the Eastern Cape Province. Onderstepoort J. Vet. Res. 1999, 66, 175-184.

18. Walker, J.B.; Keirans, J.E.; Horak, I.G. The Genus Rhipicephalus (Acari, Ixodidae): A Guide to the Brown Ticks of the World; Cambridge University Press: Cambridge, UK, 2005.

19. James, M.C.; Gilbert, L.; Bowman, A.S.; Forbes, K.J. The heterogeneity, distribution, and environmental associations of Borrelia burgdorferi sensu lato, the agent of Lyme borreliosis, in Scotland. Front. Public Health 2014, 2, 129. [CrossRef] 
20. Bhoora, R.; Franssen, L.; Oosthuizen, M.C.; Guthrie, A.J.; Zweygarth, E.; Penzhorn, B.L.; Jongejan, F.; Collins, N.E. Sequence heterogeneity in the 18S rRNA gene within Theileria equi and Babesia caballi from horses in South Africa. Vet. Parasitol. 2009, 159, 112-120. [CrossRef]

21. Lee, P.Y.; Costumbrado, J.; Hsu, C.Y.; Kim, Y.H. Agarose gel electrophoresis for the separation of DNA fragments. J. Vis. Exp. 2012, 3923. [CrossRef]

22. Kearse, M.; Moir, R.; Wilson, A.; Stones-Havas, S.; Cheung, M.; Sturrock, S.; Buxton, S.; Cooper, A.; Markowitz, S.; Duran, C.; et al. Geneious Basic: An integrated and extendable desktop software platform for the organization and analysis of sequence data. Bioinformatics 2012, 28, 1647-1649. [CrossRef]

23. Kumar, S.; Stecher, G.; Tamura, K. MEGA7: Molecular evolutionary genetics analysis version 7.0 for bigger datasets. Mol. Biol. Evol. 2016, 33, 1870-1874. [CrossRef]

24. Saitou, N.; Nei, M. The neighbor-joining method: A new method for reconstructing phylogenetic trees. Mol. Biol. Evol. 1987, 4, 406-425.

25. Felsenstein, J. Confidence limits on phylogenies: An approach using the bootstrap. Evolution 1985, 39, 783-791. [CrossRef]

26. Tamura, K.; Nei, M.; Kumar, S. Prospects for inferring very large phylogenies by using the neighbor-joining method. Proc. Natl. Acad. Sci. USA 2004, 101, 11030-11035. [CrossRef]

27. Nei, M.; Kumar, S. Molecular Evolution and Phylogenetics; Oxford University Press: Oxford, UK, 2000.

28. Maji, C.; Goel, P.; Suthar, A.; Mandal, K.D.; Gopalakrishnan, A.; Kumar, R.; Kumar, S. Lumefantrine and o-choline-Parasite metabolism specific drug molecules inhibited in vitro growth of Theileria equi and Babesia caballi in MASP culture system. Ticks Tick-Borne Dis. 2019, 10, 568-574. [CrossRef]

29. Vannier, E.; Krause, P.J. Human babesiosis. N. Engl. J. Med. 2012, 366, 2397-2407. [CrossRef]

30. Lempereur, L.; Shiels, B.; Heyman, P.; Moreau, E.; Saegerman, C.; Losson, B.; Malandrin, L. A retrospective serological survey on human babesiosis in Belgium. Clin. Microbiol. Infect. 2015, 21, 96.e1-96.e7. [CrossRef]

31. Peniche-Lara, G.; Balmaceda, L.; Perez-Osorio, C.; Munoz-Zanzi, C. Human Babesiosis, Yucatán State, Mexico. Emerg. Infect. Dis. 2018, 24, 2061. [CrossRef]

32. Khukhuu, A.; Lan, D.T.B.; Long, P.T.; Ueno, A.; Li, Y.; Luo, Y.; de Macedo, A.C.C.; Matsumoto, K.; Inokuma, H.; Kawazu, S.I.; et al. Molecular epidemiological survey of Theileria orientalis in Thua Thien Hue province, Vietnam. J. Vet. Med Sci. 2011, 73, 701-705. [CrossRef]

33. Morrison, W.I. The aetiology, pathogenesis and control of theileriosis in domestic animals. Rev. Sci. Tech. 2015, 34, 599-611. [CrossRef]

34. Dantas-Torres, F.; Otranto, D. Theileriosis. In Arthropod Borne Diseases; Springer: Cham, Switzerland, 2017; pp. 355-361.

35. Tonetti, N.; Berggoetz, M.; Rühle, C.; Pretorius, A.M.; Gern, L. Ticks and tick-borne pathogens from wildlife in the Free State Province, South Africa. J. Wildl. Dis. 2009, 45, 437-446. [CrossRef]

36. Molaei, G.; Andreadis, T.G.; Anderson, J.F.; Stafford, K.C., III. An Exotic Hitchhiker: A Case Report of Importation into Connecticut from Africa of the Human Parasitizing Tick, Hyalomma truncatum (Acari: Ixodidae). J. Parasitol. 2018, 104, 302-305. [CrossRef]

37. Criado-Fornelio, A.; Buling, A.; Pingret, J.L.; Etievant, M.; Boucraut-Baralon, C.; Alongi, A.; Agnone, A.; Torina, A. Hemoprotozoa of domestic animals in France: Prevalence and molecular characterization. Vet. Parasitol. 2009, 159, 73-76. [CrossRef]

38. Altangerel, K.; Sivakumar, T.; Inpankaew, T.; Jittapalapong, S.; Terkawi, M.A.; Ueno, A.; Xuan, X.; Igarashi, I.; Yokoyama, N. Molecular prevalence of different genotypes of Theileria orientalis detected from cattle and water buffaloes in Thailand. J. Parasitol. 2011, 97, 1075-1079. [CrossRef]

39. Li, Y.; Liu, Z.; Liu, J.; Yang, J.; Li, Q.; Guo, P.; Guan, G.; Liu, G.; Luo, J.; Yin, H.; et al. Seroprevalence of bovine theileriosis in northern China. Parasites Vectors 2016, 9, 591. [CrossRef]

40. Watts, J.G.; Playford, M.C.; Hickey, K.L. Theileria orientalis: A review. N. Z. Vet. J. 2016, 64, 3-9. [CrossRef]

41. Aparna, M.; Ravindran, R.; Vimalkumar, M.B.; Lakshmanan, B.; Rameshkumar, P.; Kumar, K.A.; Promod, K.; Ajithkumar, S.; Ravishankar, C.; Devada, K.; et al. Molecular characterization of Theileria orientalis causing fatal infection in crossbred adult bovines of South India. Parasitol. Int. 2011, 60, 524-529. [CrossRef]

42. Yokoyama, N.; Sivakumar, T.; Ota, N.; Igarashi, I.; Nakamura, Y.; Yamashina, H.; Matsui, S.; Fukumoto, N.; Hata, H.; Kondo, S.; et al. Genetic diversity of Theileria orientalis in tick vectors detected in Hokkaido and Okinawa, Japan. Infect. Genet. Evol. 2012, 12, 1669-1675. [CrossRef] 
43. Kohli, S.; Atheya, U.K.; Srivastava, S.K.; Banerjee, P.S.; Garg, R. Outbreak of theileriosis and anaplasmosis in herd of holstein crossbred cows of Dehradun district of Uttranchal, India: A Himalyan region. Int. J. Livest. Prod. 2014, 5, 6-9.

44. Jenkins, C. Bovine theileriosis in Australia: A decade of disease. Microbiol. Aust. 2018, 39, 215-219. [CrossRef]

45. Kamau, J.; de Vos, A.J.; Playford, M.; Salim, B.; Kinyanjui, P.; Sugimoto, C. Emergence of new types of Theileria orientalis in Australian cattle and possible cause of theileriosis outbreaks. Parasites Vectors 2011, 4, 22. [CrossRef]

46. Eamens, G.J.; Gonsalves, J.R.; Jenkins, C.; Collins, D.; Bailey, G. Theileria orientalis MPSP types in Australian cattle herds associated with outbreaks of clinical disease and their association with clinical pathology findings. Vet. Parasitol. 2013, 191, 209-217. [CrossRef]

47. Hammer, J.F.; Emery, D.; Bogema, D.R.; Jenkins, C. Detection of Theileria orientalis genotypes in Haemaphysalis longicornis ticks from southern Australia. Parasites Vectors 2015, 8, 229. [CrossRef]

48. Pulford, D.J.; McFadden, A.M.J.; Hamilton, J.S.; Donald, J. Investigation of the index case herd and identification of the genotypes of Theileria orientalis associated with outbreaks of bovine anaemia in New Zealand in 2012. N. Z. Vet. J. 2016, 64, 21-28. [CrossRef]

49. McFadden, A.M.J.; Hart, M.; Bueno, I.M.; Ha, H.J.; Heath, A.C.G.; Pulford, D.J. Monitoring Theileria orientalis (Ikeda)-associated bovine anaemia in affected cattle over time. Vet. Parasitol. 2017, 245, 29-33. [CrossRef]

50. Kiltz, H.H.; Uilenberg, G.; Franssen, F.F.; Perié, N.M. Theileria orientalis occurs in Central Africa. Res. Vet. Sci. 1986, 40, 197-200. [CrossRef]

51. Thompson, B.E.; Latif, A.A.; Oosthuizen, M.C.; Troskie, M.; Penzhorn, B.L. Occurrence of Theileria parva infection in cattle on a farm in the Ladysmith district, KwaZulu-Natal, South Africa. J. S. Afr. Vet. Assoc. 2008, 79, 31-35. [CrossRef]

52. Michel, A.L.; Bengis, R.G. The African buffalo: A villain for inter-species spread of infectious diseases in southern Africa. Onderstepoort J. Vet. Res. 2012, 79, 26-30. [CrossRef]

53. Altangerel, K.; Battsetseg, B.; Battur, B.; Sivakumar, T.; Batmagnai, E.; Javkhlan, G.; Tuvshintulga, B.; Igarashi, I.; Matsumoto, K.; Inokuma, H.; et al. The first survey of Theileria orientalis infection in Mongolian cattle. Vet. Parasitol. 2011, 182, 343-348. [CrossRef]

54. Bawm, S.; Shimizu, K.; Hirota, J.I.; Tosa, Y.; Htun, L.L.; Maw, N.N.; Thein, M.; Kato, H.; Sakurai, T.; Katakura, K. Molecular prevalence and genetic diversity of bovine Theileria orientalis in Myanmar. Parasitol. Int. 2014, 63, 640-645. [CrossRef]

55. Ota, N.; Mizuno, D.; Kuboki, N.; Igarashi, I.; Nakamura, Y.; Yamashina, H.; Hanzaike, T.; Fujii, K.; Onoe, S.; Hata, H.; et al. Epidemiological survey of Theileria orientalis infection in grazing cattle in the eastern part of Hokkaido, Japan. J. Vet. Med Sci. 2009, 71,937-944. [CrossRef]

56. Elsify, A.; Sivakumar, T.; Nayel, M.; Salama, A.; Elkhtam, A.; Rizk, M.; Mosaab, O.; Sultan, K.; Elsayed, S.; Igarashi, I.; et al. An epidemiological survey of bovine Babesia and Theileria parasites in cattle, buffaloes, and sheep in Egypt. Parasitol. Int. 2015, 64, 79-85. [CrossRef]

57. d'Oliveira, C.; Van Der Weide, M.; Habela, M.A.; Jacquiet, P.; Jongejan, F. Detection of Theileria annulata in blood samples of carrier cattle by PCR. J. Clin. Microbiol. 1995, 33, 2665-2669. [CrossRef]

58. Shahnawaz, S.; Ali, M.; Aslam, M.A.; Fatima, R.; Chaudhry, Z.I.; Hassan, M.U.; Iqbal, F. A study on the prevalence of a tick-transmitted pathogen, Theileria annulata, and hematological profile of cattle from Southern Punjab (Pakistan). Parasitol. Res. 2011, 109, 1155. [CrossRef]

59. Oryan, A.; Namazi, F.; Sharifiyazdi, H.; Razavi, M.; Shahriari, R. Clinicopathological findings of a natural outbreak of Theileria annulata in cattle: An emerging disease in southern Iran. Parasitol. Res. 2013, 112, 123-127. [CrossRef]

60. Gomes, J.; Salgueiro, P.; Inácio, J.; Amaro, A.; Pinto, J.; Tait, A.; Shiels, B.; da Fonseca, I.P.; Santos-Gomes, G.; Weir, W. Population diversity of Theileria annulata in Portugal. Infect. Genet. Evol. 2016, 42, 14-19. [CrossRef]

61. Memon, M.I.; Memon, N.; Kachiwal, A.B.; Memon, M.R.; Bhutto, B. Prevalence of Theileriosis and its impact on haemotological values in naturally infected buffaloes at Hyderabad. Pak. J. Agric. Agric. Eng. Vet. Sci. 2016, 32, 85-94.

62. Khawale, T.S.; Siddiqui, M.F.M.F.; Borikar, S.T.; Sakhare, M.P.; Rajurkar, S.R.; Chigure, G.M.; Shafi, T.A. Study of occurrence of theileriosis in cattle from Parbhani district, Maharashtra, India. Pharma. Innov. 2019, 8, 171-173. 
63. Amira, A.H.; Ahmed, L.; Ahmed, J.; Nijhof, A.; Clausen, P.H. Epidemiological study on tropical theileriosis (Theileria annulata infection) in the Egyptian Oases with special reference to the molecular characterization of Theileria spp. Ticks Tick-Borne Dis. 2018, 9, 1489-1493.

64. Guo, H.; Yin, C.; Galon, E.M.; Du, J.; Gao, Y.; Moumouni, P.F.A.; Liu, M.; Efstratiou, A.; Lee, S.H.; Li, J.; et al. Molecular survey and characterization of Theileria annulata and Ehrlichia ruminantium in cattle from Northwest China. Parasitol. Int. 2018, 67, 679-683. [CrossRef]

65. Calleja-Bueno, L.; Sainz, Á.; García-Sancho, M.; Rodríguez-Franco, F.; González-Martín, J.V.; Villaescusa, A. Molecular, epidemiological, haematological and biochemical evaluation in asymptomatic Theileria annulata infected cattle from an endemic region in Spain. Ticks Tick-Borne Dis. 2017, 8, 936-941. [CrossRef]

66. Criado-Fornelio, A.; Martinez-Marcos, A.; Buling-Sarana, A.; Barba-Carretero, J.C. Molecular studies on Babesia, Theileria and Hepatozoon in southern Europe: Part II. Phylogenetic analysis and evolutionary history. Vet. Parasitol. 2003, 114, 173-194. [CrossRef]

67. Ybañez, A.P.; Tagawa, M.; Matsumoto, K.; Kishimoto, T.; Yokoyama, N.; Inokuma, H. Specific molecular detection of Anaplasma sp. closely related to Anaplasma phagocytophilum in Ixodid ticks and cattle in a pastureland in Hokkaido, Japan. Vector-Borne Zoonotic Dis. 2013, 13, 6-11. [CrossRef]

68. Jafarbekloo, A.; Ramzgouyan, M.R.; Shirian, S.; Tajedin, L.; Bakhshi, H.; Faghihi, F.; Sedaghat, M.; Telmadarraiy, Z. Molecular characterization and phylogenetic analysis of Theileria spp. and Babesia spp. isolated from various ticks in southeastern and northwestern regions of Iran. Vector-Borne Zoonotic Dis. 2018, 18, 595-600. [CrossRef]

69. Lledó, L.; Gegúndez, M.I.; Giménez-Pardo, C.; Álamo, R.; Fernández-Soto, P.; Nuncio, M.S.; Saz, J.V. A seventeen-year epidemiological surveillance study of Borrelia burgdorferi infections in two provinces of northern Spain. Int. J. Environ. Res. Public Health 2014, 11, 1661-1672. [CrossRef]

70. Levi, M.M.; Nachum-Biala, Y.; King, R.; Baneth, G. A survey of Babesia spp. and Hepatozoon spp. in wild canids in Israel. Parasites Vectors 2018, 11, 150. [CrossRef]

Publisher's Note: MDPI stays neutral with regard to jurisdictional claims in published maps and institutional affiliations.

(C) 2020 by the authors. Licensee MDPI, Basel, Switzerland. This article is an open access article distributed under the terms and conditions of the Creative Commons Attribution (CC BY) license (http://creativecommons.org/licenses/by/4.0/). 